Moderation or radicalisation? How executive power affects right-wing populists' satisfaction with democracy

\author{
Atle Haugsgjerd ${ }^{\mathrm{b}}$ \\ ${ }^{a}$ Department of Political Science, University of Oslo, Oslo, Norway \\ ${ }^{b}$ Institute for Social Research, Oslo, Norway
}

Email: a.h.haugsgjerd@ samfunnsforskning.no 


\section{Moderation or radicalisation? How executive power affects right-wing populists' satisfaction with democracy}

This paper investigates if access to executive power strengthens or weakens the positive relationship found in previous research between dissatisfaction with democracy and electoral support for the populist right. Research on political trust and satisfaction with democracy thus far has almost exclusively focused on cases in which the populist right has been excluded from governing coalitions. Will access to executive power incite these parties to moderate their populist rhetoric and boost satisfaction among their supporters, or will limited policy impact and sustained populist messages even from within governments generate disappointment and therefore exacerbate dissatisfaction with the political system? This study investigates one of the few countries in Europe where a populist rightwing party has assumed national office, namely Norway. Using individual-level panel data I find support for the moderation perspective in that assuming office indeed weakens the relationship between dissatisfaction with democracy and electoral support for the populist right.

Keywords: satisfaction with democracy; political trust; populist right-wing support; panel data 


\section{Introduction $^{1}$}

The electoral rise of populist right-wing parties has spurred widespread concerns that established democracies are suffering from a crisis of political legitimacy. This party family has based its identity and appeal on an anti-establishment profile and frequently expresses distrust in the institutions of representative democracies. It has recently been argued that political distrust and support for the populist right even reinforce one another. It is claimed that voters turn to populist right-wing parties to express their political distrust, which makes for an even stronger belief in the untrustworthiness of the political institutions of representative democracies (Hooghe and Dassonneville 2016).

A fundamental question concerning political trust in established democracies is whether the increased electoral strength of this party family might temper their supporters' distrust. Due to increased electoral support, populist right-wing parties have permeated the governments of a small number of European countries, surmounting what Rokkan (1970:79) once described as the final institutional threshold any rising political movement must pass on their way 'inwards toward the core of the political system'. How will this transition affect populist-right wing supporters' satisfaction with democracy? On the one hand, access to executive power might incite these parties to moderate their populist rhetoric and boost satisfaction among their supporters. On the other hand, limited policy impact and sustained populist messages even from within governments might generate disappointment and therefore exacerbate dissatisfaction with the political system. As research on political trust thus far has almost exclusively

${ }^{1}$ I would like in particular to thank Stefan Dahlberg, Lisanne De Blok, Elisabeth Ivarsflaten, Anders Jupskås, Rune Karlsen, Staffan Kumlin, Øyvind Bugge Solheim and Bernt Aardal for feedback on previous drafts of this article. I also received valuable comments from participants at the Norwegian Political Science Association Meeting, 2018. 
focused on cases in which the populist right has been excluded from governing coalitions, the extent to which entrance into office might strengthen or weaken the relationship between political distrust and support for the populist right is currently unclear.

This paper investigates how supporters of a populist right-wing party respond when their party of choice assumes office and becomes responsible for government policies. By pursuing this question, it provides two contributions to the literature on political trust. First, the relationship between support for the populist right and dissatisfaction with democracy in a political system in which a member of this party family has gained access to power both in the legislative and executive arena, namely Norway, is investigated. Given Norway's long history with a populist right-wing party, which eventually managed to break free from parliamentary isolation and to gain coalition potential, Norway offers new theoretical insights.

Second, a methodological contribution is made by applying a number of different individual-level, panel-data sources. With some notable exceptions (Hooghe and Dassonneville 2016; Rooduijn, van der Brug and de Lange 2016), previous research on this topic has been cross-sectional (e.g. Bélanger and Nadeau 2005). This study improves previous research by utilising both a series of two-wave, post-election panels from the Norwegian National Election Study (NNES) to estimate change score models (Finkel 1995) and unique seven-wave panel data from the Norwegian Citizens Panel (NCP) to run a series of latent growth models (Singer and Willett 2003). Collectively, this empirical approach provides both improved causal evidence and new substantive knowledge on the dynamics of political support among populist right-wing supporters.

In the next section, current literature on the relationship between political trust and populist right-wing support, which thus far has focused on cases in which the 
populist right has been excluded from governing coalitions, is reviewed. Second, the way populist right-wing supporters might respond when their party of choice assumes office is discussed based on two competing hypotheses: a moderation thesis and a radicalisation thesis. Then, the case selection is described before discussing data and modeling strategies.

\section{Theory}

\section{Populist right-wing supporters: the distrustful outsiders}

Research on political trust has long been concerned with the impact of distrust on voting behaviour in general and on support for populist right-wing parties specifically. A key finding in this literature is that populist right-wing supporters deviate from other groups in their lack of political trust (See review by Bélanger 2017). Two different mechanisms seem to underlie this relationship.

First, people turn to right-wing populist parties to express their distrust with mainstream parties and with the performance of the political system in general (Bélanger and Aarts 2006). Voting motivated by political distrust is often referred to as 'protest voting' and implies that political trust is the cause of the voting choice (e.g. Bergh 2004). Granted, in two-party systems, protest votes tend to benefit the party in opposition - if distrustful voters choose to cast a vote at all (Citrin 1974; Hetherington 1999); however, in multiparty systems, populist right-wing parties offer distrustful voters a means of representation through their anti-establishment profile and allow distrustful voters to express their frustrations through the ballot box (Bélanger and Nadeau 2005; Miller and Listhaug 1990).

Another group of studies challenges the notion that political trust is exogenous to vote choice. Instead, political distrust is conceived as a consequence of support for 
the populist right (e.g. Van der Brug 2003). These studies argue that electoral support for these parties is primarily driven by policy preferences (Van der Brug, Fennema and Tillie 2005). That is, they contend that people vote primarily for these parties because they represent specific policy positions, particularly a strong stand against immigration. Furthermore, these studies highlight that voters tend to take cues from and adapt to political viewpoints of parties they are sympathetic to (Lenz 2012). Consequently, when leaders of the populist right convey anti-establishment messages, they fuel political distrust among their supporters.

Although these two arguments (that trust is a cause or a consequence of voting choice) are theoretically antithetical, both processes may occur empirically. Indeed, recent panel studies suggest there is a reciprocal relationship. Rooduijn, van der Brug and de Lange (2016) examined the relationship between populist voting — both left- and right-wing populism — and political discontent in the Netherlands. Based on a six-wave panel study (2008-2013), they concluded that political discontent is both a cause and a consequence of the rise of populist parties. Hooghe and Dassonneville (2016) investigated the relationship between voting for the populist right and political trust in Belgium during a two-wave, five-year (2009-2014) panel study. They found evidence of a reciprocal relationship in which distrust and protest voting reinforce one another. They thus described the relationship as a 'spiral of distrust' that causes distrustful groups to turn to populist right-wing parties, which makes for an even stronger belief in the untrustworthiness of political institutions of representative democracies.

A fundamental question is whether the positive relationship between political distrust and support for the populist right is weakened or even reversed if this party family obtain access to executive power. As pointed out by Hooghe (2018:629), this is still largely an unanswered question in the literature despite the recent electoral rise of 
the populist right. Admittedly, with regard to the abovementioned study of Rooduijn, van der Brug and de Lange (2016), the Party for Freedom (PVV) in the Netherlands was a formal support party for the Rutte I government (2010-2012) for a short period; however, the party withdrew their support and dissolved the government in 2012 and has since been ousted by the other mainstream parties on the right. Another exception is the study of Bergh (2004) of protest voting in Austria in 2000 when the Freedom Party of Austria (FPÖ) was in power for the first time. Interestingly, he found that contrary to opposition during the 1990s, supporters of FPÖ did not deviate from supporters of other parties regarding their trust in political institutions. In other words, he found no evidence of protest voting when FPÖ was in government. Notwithstanding the importance of this study, Bergh's findings are based on cross-sectional data, and it is therefore uncertain whether FPÖ's access to executive power actually generated changes in trust.

Taken together, the foci of previous research have been party-systems in which populist right-wing parties have had a limited influence on public policy through the parliamentary channel. Thus, the question regarding how executive power affects rightwing populists' satisfaction with democracy remains largely unanswered. This study takes a first step to fill this lacuna by investigating the Norwegian case using individuallevel panel-data.

\section{The move inside: Moderation or radicalisation?}

Previous research does not provide clear-cut expectations with respect to how access to executive power affects right-wing populists' satisfaction with democracy. Instead, previous findings collectively substantiate both a 'moderation hypothesis' predicting that the gap in satisfaction between populist right-wing supporters and non-populist 
right-wing supporters would level out as the party assumes office and a 'radicalisation hypothesis' predicting that the gap would be sustained or even strengthened. Thus, in this section, two competing hypotheses regarding how supporters of the populist right respond to national office are compared. It should be stated clearly that these hypotheses only concerns changes in populist right wing supporters' general attitudes towards the working of democracy, and do not concern how their policy attitudes - such as their views on immigration - are affected by executive power.

The moderation hypothesis draws on two sets of findings. The first set is related to the reoccurring verdict that electoral winners and losers differ in their evaluations of the political system (e.g. Anderson et al. 2005; Curini, Jou and Memoli 2012; Dahlberg and Linde 2016). Simply put, ample research has shown that voters who win elections are more satisfied with democracy than voters who lose elections. This satisfaction gap is attributed to both cognitive and emotional reactions triggered by electoral participation, including (but not restricted to) the expected utility of future public policies, and to emotional reactions to being on the winning or losing 'team' (Anderson et al. 2005). Thus, given that populist right-wing supporters respond to winning an election as other voters tend to respond, a boost in satisfaction with democracy should be expected once the populist right assumes national office. Such an effect should occur instantly after an election as it is triggered by voters' own experiences with being on either the winning or the losing team in a given election.

Second, recent party research has shown that in some instances, inclusion into office has incited populist right-wing parties to moderate their previous policy positions 
and rhetoric (Akkerman, de Lange and Rooduijn 2016c). ${ }^{2}$ Generally, first-time access to executive power leads to a number of incentives for parties to change and adapt to the demands of national office (Deschouwer 2008). In the electoral arena, parties must balance vote- and office-seeking ambitions constantly, risking a loss of credibility among core supporters because of compromises, especially for issues that parties have used to develop identity and appeal. In addition, government participation often requires substantial organisational adaption as well as a constant nurturing of workingrelationships with coalition partners (Luther 2011). While these are generic challenges common to any party entering office for the first time, they are arguably even stronger for right-wing populist parties that have based their electoral appeal (partly) on an outsider profile (McDonnell and Newell 2011). Thus, populist right-wing parties might have particularly strong reasons to change once entering office. In turn, moderation may dampen their ability to fuel distrust among their supporters. Any such effect would likely not occur immediately after an election, but rather play out in the long-term as the rhetoric of the party elite adapts to the demands of national office.

Taken together, two different findings in previous research support the moderation thesis. However, these two findings highlight different mechanisms; one relating to voters' experience with the electoral outcome in a short-term perspective and one external to the voters relating to the parties' long-term behavior in office.

\footnotetext{
${ }^{2}$ Empirical evidence on this point is mixed. For instance, Akkerman, de Lange and Rooduijn (2016b:41-42) found that The Danish People's Party (DF) has undergone a mainstreaming process and has de-radicalised their policy positions while being a formal support party for the conservative coalition government in Denmark. On the other hand, the Swiss People's Party (SVP) has become increasingly radicalised during its time in government.
} 
Importantly, the two mechanisms are not necessarily contradictory; both may occur empirically. Thus, the two threads of research substantiate the following hypotheses:

H1A: The gap in satisfaction with democracy between populist right-wing supporters and non-populist right-wing supporters will decrease shortly after the election as the populist right-wing party assumes government office.

H1B: The gap in satisfaction with democracy between populist right-wing supporters and non-populist right-wing supporters will gradually decrease in the long-term as the populist right-wing party assumes government office.

Other studies provide justifications to suspect that populist right-wing supporters respond critically to access to executive power. The radicalisation hypothesis is based on research that has shown that in cases in which populist right-wing parties actually have assumed office, their policy impacts have often been limited. In a review-article on the impact of the populist right, Cas Mudde (2013) concluded that the government records of these parties do 'not look very impressive, even on their key issue of immigration'. Thus, he advised against strong conclusions with respect to the policy impact of this party family and argued that alongside 'any successes on immigration stand many failures as well'(Mudde 2013:9-10). Most likely, this verdict not only pertains to the immigration issue but also to economic and welfare-related issues second to this party family. A limited policy impact may generate disappointment among its supporters, which in turn might fuel political discontent.

Furthermore, when in government, right-wing populist parties often pursue what Albertazzi and McDonnell (2005) referred to as 'one foot in, one foot out-strategies' aiming to balance vote- and office-seeking ambitions. Rather than responding to the demands of national office by taming their rhetoric, in the past, successful populist right-wing parties have 'managed to achieve the balancing act of being seen to influence 
policy on its core issues while maintaining its "outsider" identity through a series of statements and “spectacular" actions' (Albertazzi and McDonnell 2010:1319). By continuing to voice concerns of disaffected voters from a position of public office, populist right-wing parties may continue to evoke political discontent among their supporters. This split-strategy may be particularly effective in cases in which the populist right joins or supports a minority government with greater opportunities to maintain an anti-establishment profile than majority coalitions (Akkerman, de Lange and Rooduijn 2016a:15).

In light of these arguments, the following counter-hypothesis was developed:

$\mathrm{H} 2$ : The gap in satisfaction with democracy between populist right-wing supporters and non-populist right-wing supporters will persist or strengthen as the populist right-wing party assumes government office.

\section{Case selection}

Norway is part of a small group of countries in Europe where a populist right-wing party has assumed national office. The Norwegian Progress Party (Fremskrittspartiet, FrP) was founded in 1973 during what has been labelled the 'second wave' of far-right mobilisation in Western Europe, but it emerged as an important player in Norwegian politics in the late 1980s, fuelled in part by voter mobilisation based on an antiimmigration message (Jupskås 2015). It is fair to say that currently, FrP is moderate compared to other parties traditionally included in this party family, and some have even argued that it is somewhat a borderline case (Mudde 2007). Yet, the three core elements of right-wing populism—nativism, authoritarianism and populism—are indeed defining features of FrP (Aardal and Bergh 2015; Bjånesøy and Ivarsflaten 2016; Ivarsflaten 2008; Jupskås 2015). Thus, FrP's transition to power in 2013 is an example of the recent surge of the populist right in Europe characterised by increased influence 
in parliaments, and in some cases, access to executive office.

Norwegian citizens are on average, compared to citizens of most other countries, satisfied with the way (their national) democracy works. The most recent data from European Social Survey (2016) shows that Norwegians have an average level of satisfaction at approximately 7.20 on a $0-10$ scale. ${ }^{3}$ This is the second highest level of satisfaction among all the countries in the data (behind Switzerland). In terms of longitudinal developments in political support, Norway has in recent years displayed a trajectory similar to most other Western and Northern European countries characterised by stable or slightly increasing overall levels (Torcal 2017). These observations corresponds well with previous research portraying Norway as a consensual political system with low threshold of representation and high levels of political support (Bengtsson et al. 2014; Miller and Listhaug 1990; Norris 2011). Yet, as will be evident in the empirical section, although this general description is appropriate for the majority of the Norwegian electorate, it disregards a large voter group attracted by the populist right who is more dissatisfied with the functioning of the political system and its political institutions.

By both pursuing and fulfilling office-seeking ambitions, FrP has clearly transcended the typical function of protest parties in multi-party systems as vehicles for dissatisfied voters (Bélanger 2017). After a period of radicalisation and strengthening their outsider-profile in the second half of the 1990s, the party gradually developed office-seeking ambitions in the early 2000s and began to improve their working relationships with other non-socialist parties. The replacement of long-time chairman

\footnotetext{
${ }^{3}$ See Figure A1 in the appendix for mean levels of satisfaction with democracy by country in Europe.
} 
Carl I. Hagen by the more cooperative Siv Jensen in 2006 was an important step in this process. Equally important was the expulsion of extremist members of the party in the late 1990s and early 2000s (Jupskås 2016). In 2009, the conservative party (Høyre, H) finally decided to embrace $\mathrm{FrP}$ as a potential coalition partner, and four years later, the party assumed office for the first time as a junior partner in a minority coalition with the conservative party (Allern 2010; Allern and Karlsen 2014). Since then, the party has clearly demonstrated that it is capable of governing, which in turn has raised its status as a legitimate player in the game of democratic politics.

At the same time, the totality of the party's image and conduct since assuming office is arguably best captured by Albertazzi and McDonnell's (2005) 'one-foot-inone-foot-out' concept. While Siv Jensen and other key members of government have displayed (fairly) cautionary conduct typical of mainstream politicians in office, prominent members of their group in parliament have simultaneously sustained a vocal populist profile (Fangen and Vaage 2015; Jupskås 2016). This split between different fractions of the party has become increasingly evident as the party has been forced to make compromises in government. Recently, strong populist messages have even been advocated from the party's governmental branch as politicians with stout antiestablishment profiles have replaced moderate members of the cabinet. Taken together, since assuming office, FrP has both been eager to demonstrate its ability to behave responsibly and to ensure its supporters that its populist profile is still alive.

Before presenting the empirics, it should be clearly stated that although Norway offers interesting theoretical insights, the findings will inevitably be context-sensitive. Therefore, in the concluding section, various factors that are likely to play a role in explaining comparative variations are discussed. 


\section{Data, research design and measurements}

The analysis proceeded in three steps. First, data from the European Social Survey (ESS) were used to obtain an initial longitudinal overview of satisfaction with democracy. The ESS is particularly useful for this purpose because it provides highquality data with relatively short time intervals (collected every second year), covering both the period before and after FrP entered government. Moreover, these data were used to run a number of cross-sectional regression models to compare the magnitude of the cross-sectional relationship before and after FrP assumed office.

Then, individual-level dynamics were examined using panel-data. Specifically, two different data sources were utilised. To investigate the relationship in question before FrP entered government, a series of two-wave post-election panels from the Norwegian National Election Study (NNES) was used. The purpose of using these data sources was to determine whether supporters of FrP displayed dynamics typical of populist right-wing supporters when FrP was still not considered to have coalition potential by other mainstream parties. Specifically, the empirical strategy of Hooghe and Dassonneville (2016) was followed to assess whether support for the populist right at $t_{1}$ causes changes in satisfaction with democracy from $t_{1}$ to $t_{2}$. Four different panels covering the period from 1997 to 2013 were used. ${ }^{4}$ Crucially, the final panel in this series (2009-2013) allowed for determining whether FrP's entrance into government in 2013 generated any immediate changes in its dynamics.

Finally, to examine populist right-wing supporters' long-term dynamics related to satisfaction after FrP assumed government office, the Norwegian Citizens Panel (NCP) (Ivarsflaten 2017) was used. The NCP consists of seven waves of panel-data that

\footnotetext{
${ }^{4}$ Panels 1997-2001, 2001-2005, 2005-2009, 2009-2013.
} 
were collected every six months throughout the first three years of the 2013-2017 electoral cycle. These data are important for the purpose of this article because some of the arguments underlying the hypotheses that are to be tested concern the behaviours of the party during its time in office. Combining the NNES and NCP allowed for gauging both short- and long-term dynamics related to satisfaction with democracy in response to FrP's entrance into government office.

All seven waves of NCP were used by estimating a series of latent growth models (Singer and Willett 2003). These are multilevel models where each individual is conceived as the upper level in the data hierarchy (level two), while observations of each individual are conceived as the lower level (level one). A basic growth model can be represented by the equation

$$
\mathrm{Y}_{\mathrm{it}}=\beta_{0 \mathrm{i}}+\beta_{1 \mathrm{i}} \text { Time }+\varepsilon_{\mathrm{it}}(1)
$$

where the outcome variable Y (or satisfaction with democracy) for a particular unit (i) at a particular point in time $(\mathrm{t})$ is simply modelled as a function of an intercept and time. Crucially, in latent growth models each individual has its own intercept as well as its own slope (or rate of change) over time (Plutzer 2002). For the purpose of this article, this allows me to separate between two different types of variation in satisfaction with democracy: variation in individuals' starting levels in satisfaction located at level two, and within-individual changes (or growth) in satisfaction over time at level one.

Individuals' starting level in satisfaction can be represented by the equation

$$
\beta_{0 \mathrm{i}}=\gamma_{00}+\gamma_{01} Z+\mu_{0 \mathrm{i}}(2)
$$

where $\beta_{0 \mathrm{i}}$ is the intercept from equation (1), $\gamma_{00}$ is an intercept, $\mathrm{Z}$ is a variable that affects initial satisfaction levels, $\gamma_{01}$ is the effect of $\mathrm{Z}$ on initial satisfaction, while $\mu_{0 \mathrm{i}}$ is the 
unexplained variance in person i's starting level. This part of the growth model facilitates a study of whether populist right-wing supporters began at the same level of satisfaction as other voters immediately after the 2013 parliamentary election.

Individuals' rate of change over time is represented by the equation

$$
\beta_{1 \mathrm{i}}=\gamma_{10}+\gamma_{11} \mathrm{Z}+\mu_{1 \mathrm{i}}(3)
$$

where $\beta_{1 \mathrm{i}}$ is the slope parameter from equation (1), $\gamma_{10}$ is an intercept, $\mathrm{Z}$ is a predictor of the rate of change in satisfaction with democracy, $\gamma_{11}$ is the effect of $\mathrm{Z}$ on the rate of change in satisfaction, while $\mu_{0 \mathrm{i}}$ is the unexplained variance in person i's growth rate. This part of the growth model facilitates a study of whether populist-right wing supporters' changes in satisfaction during the 2013-2017 electoral cycle differ from that of other groups. ${ }^{5}$

I run the analyses on the full panel (i.e. an unbalanced panel). A major advantage of the latent growth model for change is that it is easy to fit to unbalanced data. This allows for using as much as possible of the information in the data when estimating the models (see Singer and Willett (2003:146-159) for a discussion). However, imbalances in the data due to for instance non-random attrition may invalidate the generalisability of the inferences made. Thus, I also run the growth models using multiple imputation, and report the results in the appendix.

For the measurements, the dependent variable is the often-used 'Satisfaction with democracy' item. In the NNES data, the question is formulated as follows: 'On the whole, would you say that you are very satisfied, fairly satisfied, not very satisfied or

\footnotetext{
${ }^{5}$ See Dahlberg and Linde (2016) and Plutzer (2002) for other applications of latent growth models in political science research.
} 
not at all satisfied with the way democracy is functioning in Norway?' It is scaled from 1 (not at all satisfied) to 4 (very satisfied). The question wording is identical for the $\mathrm{NCP}$ and ESS but with different response categories. For the NCP, categories vary from 1 (not at all satisfied) to 5 (very satisfied), and for the ESS, respondents are presented with an 11-point continuous scale (0-10). Thus, absolute levels should not be compared across the different data sets. The satisfaction with democracy item is well-suited for the purpose of this paper as it captures citizens' support for regime performance, one of the key dimensions of political support (Newton 2008; Norris 2011). Moreover, the question is asked as the only relevant indicator consistently in all waves of both the NNES data and the NCP data. This is a frequently used indicator in political trust literature, and the findings of this paper should thus be generalisable to other studies in the field. ${ }^{6}$

\section{Analyses}

Has FrP's entrance into office strengthened or weakened the relationship between dissatisfaction with democracy and support for the populist right? To provide an initial overview, the analysis begins by presenting simple descriptive longitudinal statistics on satisfaction with democracy. Figure 1 displays the mean levels of satisfaction on an 11point scale (0-10) from 2002 to 2016 by party affiliation. ${ }^{7}$ The stapled line indicates the

${ }^{6}$ See Canache, Mondak and Seligson (2001) and Linde and Ekman (2003) for discussions on how this item should be interpreted.

${ }^{7}$ The ESS does not contain a measure of vote intention in all rounds. Instead, the ESS asks which party the respondents voted for in the last national election. Consequently, in the Norwegian case, the data do not contain updated information on party preference in 2004, 2008, 2012 or 2016 due to the timing of the national parliamentary election. Fortunately, 
level of satisfaction for supporters of the Progress Party, while the black line refers to the (mean) development of all other voters. Other party-specific trajectories are shown in the background.

Figure 1. Satisfaction with democracy 2002-2016, ESS

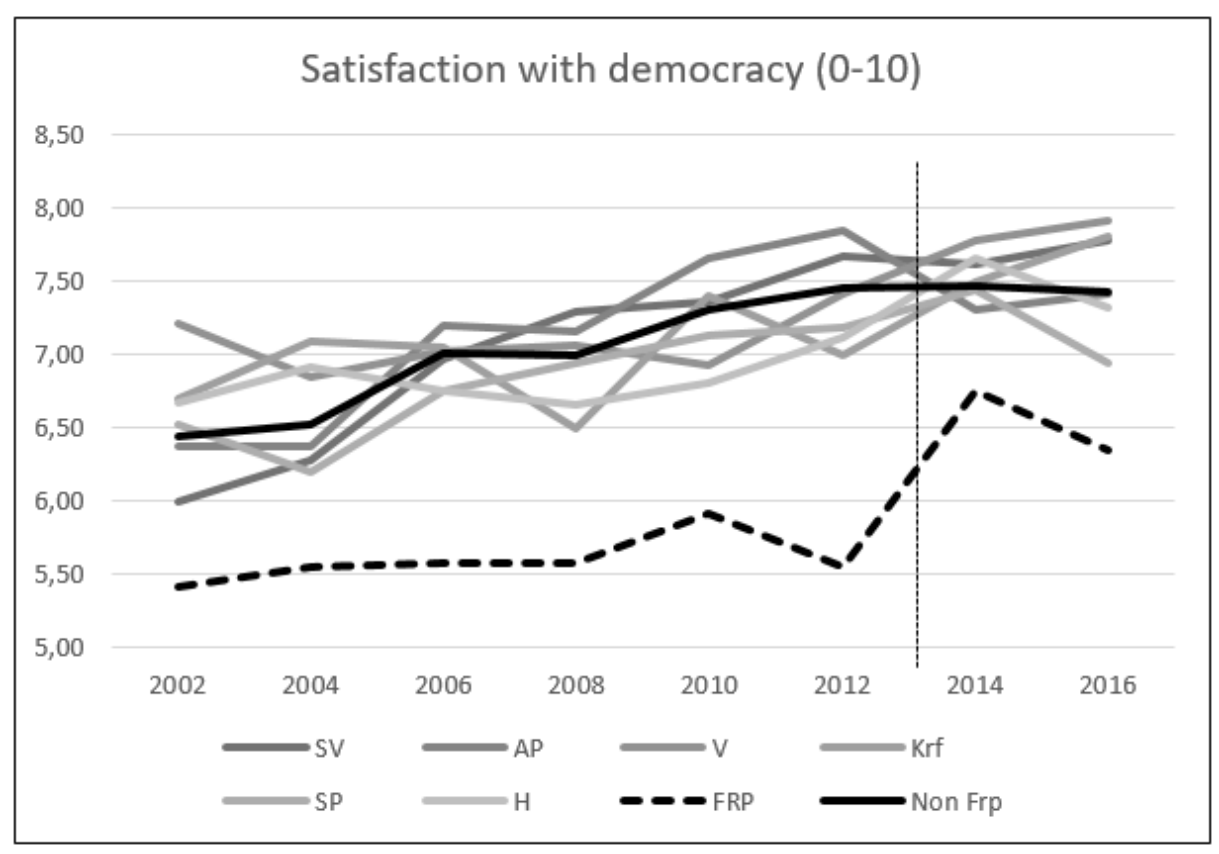

Note: The data are weighted. See Table A1 in the appendix for means and standard deviations.

This figure indicates that supporters of the populist right became more satisfied with democracy once their party of choice assumed office. During the period from 2002-2016, supporters of the Progress Party were overall less satisfied with democracy than other voters. This discrepancy is expected based on previous research (Bélanger 2017). Furthermore, voters who are not affiliated with the populist right generally experienced an increase in satisfaction throughout this period. This is also in accordance with recent studies on longitudinal developments in political trust in

party affiliation is asked in all waves, and this variable correlates with vote choice at approximately 0.9 . 
established democracies (Linde and Dahlberg 2016; van Ham et al. 2017); however, interestingly, supporters of the Progress Party did not take part in this development and remained stable at their (relative) low level of satisfaction. Thus, until 2012, the electorate became increasingly polarised in satisfaction with democracy. However, this pattern changed between 2012 and 2014 when supporters of the populist right gained a remarkable 1.2 increase in satisfaction followed by a slight decrease the next two years.

Figure 2. Magnitude of regression coefficients for populist right-wing affiliation on satisfaction with democracy. ESS 2002-2016



Note: Coefficients for populist right-wing affiliation estimated using the OLS regression. Each model includes a control for years of education, unemployment, subjective income, age and gender. See Table A2 in the appendix for coding of variables and complete results from the regression analyses.

To rule out the possibility that these developments are only due to systematic socio-economic differences among different respondents, results from a number of multivariate regression models are presented. Specifically, Figure 2 displays regression coefficients with 95 per cent confidence intervals for affiliating with the populist right 
(compared to affiliating with any other party) from eight separate cross-sectional analyses, one for each wave of the ESS. The vertical line in the figure indicates the timing of FrP's entrance into office. Clearly, at each time point, there is a significant negative coefficient for being affiliated with the populist right controlled for sociodemographic variables. Furthermore, the magnitude of this relationship increases steadily until 2012 when it suddenly dramatically decreases. Thus, the satisfaction gap seems to be sensitive to the inclusion of the populist right in government.

Overall, these initial results mainly support the theoretical expectations of the moderation hypothesis. Supporters of the populist right seem to gain a significant (absolute) increase in satisfaction with democracy once their party of choice assumes office. In addition, when this occurs, the (relative) gap in satisfaction between these voters and other groups decreased; however, as discussed, these results leave important questions about causality unanswered. They also leave the question regarding the persistence of any effect of assuming office unanswered. Figure 1 indeed suggests that the boost in satisfaction may be reduced over time. In the next two sections, these issues are addressed by analysing individual-level panel-data, beginning with the dynamics when FrP was still outside of office.

\section{Individual level dynamics outside of office}

Table 1 presents the results from a number of two-wave panel models estimated using the OLS regression that explain the respondents' changes in satisfaction with democracy from $t_{1}$ to $t_{2}$. These models are comparable to previous research in that they control for standard sociodemographic variables as well as potential floor and ceiling effects by including respondents' levels of satisfaction at $\mathrm{t}_{1}$ as an explanatory variable (Hooghe and Dassonneville 2016; Hooghe and Stiers 2016). The same model was run 
on four different post-election panels covering the period 1997-2013. ${ }^{8}$ Next, whether support for the populist right in Norway did fuel political dissatisfaction when the party was in opposition is discussed, and whether any changes occurred when FrP was included as a governing coalition partner for the first time during the period 2009-2013 is determined.

Table 1. Explaining $\Delta$ Satisfaction with Democracy 1997-2013, OLS

\begin{tabular}{|c|c|c|c|c|}
\hline & $\begin{array}{c}1997- \\
2001 \\
\end{array}$ & $\begin{array}{l}2001- \\
2005\end{array}$ & $\begin{array}{l}2005- \\
2009 \\
\end{array}$ & $\begin{array}{l}2009- \\
2013 \\
\end{array}$ \\
\hline \multirow[t]{2}{*}{ Satisfaction with democracy $\mathrm{t}_{1}$} & $0.32^{* *}$ & $0.22^{* *}$ & $0.30^{* *}$ & $0.35^{* *}$ \\
\hline & $(0.04)$ & $(0.04)$ & $(0.04)$ & $(0.04)$ \\
\hline \multirow[t]{2}{*}{ Lower educated (ref: middle) $\mathrm{t}_{1}$} & -0.07 & -0.05 & -0.08 & $-0.15^{+}$ \\
\hline & $(0.07)$ & $(0.07)$ & $(0.08)$ & $(0.08)$ \\
\hline \multirow[t]{2}{*}{ Higher educated (ref: middle) $t_{1}$} & 0.09 & -0.01 & -0.03 & 0.08 \\
\hline & $(0.05)$ & $(0.05)$ & $(0.05)$ & $(0.05)$ \\
\hline \multirow[t]{2}{*}{ Age (cont.) } & -0.00 & -0.00 & -0.00 & 0.00 \\
\hline & $(0.00)$ & $(0.00)$ & $(0.00)$ & $(0.00)$ \\
\hline \multirow{2}{*}{ Female (ref: male) } & 0.01 & -0.05 & 0.04 & 0.06 \\
\hline & $(0.05)$ & $(0.04)$ & $(0.05)$ & $(0.05)$ \\
\hline \multicolumn{5}{|l|}{ Party voted for $\mathrm{t}_{1}$ (ref: AP) } \\
\hline \multirow[t]{2}{*}{$\mathrm{R} ø \mathrm{dt} / \mathrm{RV}$} & -0.14 & -0.20 & -0.09 & $-0.43^{+}$ \\
\hline & $(0.16)$ & $(0.19)$ & $(0.18)$ & $(0.22)$ \\
\hline \multirow[t]{2}{*}{ SV } & -0.02 & -0.08 & -0.03 & 0.01 \\
\hline & $(0.09)$ & $(0.07)$ & $(0.08)$ & $(0.10)$ \\
\hline \multirow[t]{2}{*}{ SP } & -0.04 & -0.02 & -0.03 & -0.00 \\
\hline & $(0.08)$ & $(0.10)$ & $(0.09)$ & $(0.10)$ \\
\hline \multirow[t]{2}{*}{$\mathrm{KrF}$} & -0.07 & -0.11 & $-0.24^{*}$ & 0.02 \\
\hline & $(0.07)$ & $(0.07)$ & $(0.10)$ & $(0.13)$ \\
\hline \multirow[t]{2}{*}{$\mathrm{V}$} & 0.08 & -0.14 & -0.02 & -0.00 \\
\hline & $(0.11)$ & $(0.11)$ & $(0.10)$ & $(0.10)$ \\
\hline \multirow[t]{2}{*}{$\mathrm{H}$} & 0.09 & $-0.18^{* *}$ & -0.11 & 0.02 \\
\hline & $(0.07)$ & $(0.06)$ & $(0.07)$ & $(0.07)$ \\
\hline \multirow[t]{2}{*}{ FrP } & $-0.19^{*}$ & $-0.32^{* *}$ & $-0.17^{*}$ & -0.06 \\
\hline & $(0.08)$ & $(0.08)$ & $(0.07)$ & $(0.07)$ \\
\hline \multirow[t]{2}{*}{ Constant } & $1.90^{* * *}$ & $2.63^{* *}$ & $2.23^{* *}$ & $1.99^{* *}$ \\
\hline & $(0.17)$ & $(0.16)$ & $(0.17)$ & $(0.18)$ \\
\hline$N$ & 644 & 664 & 644 & 508 \\
\hline $\mathrm{r} 2$ & 0.14 & 0.10 & 0.11 & 0.17 \\
\hline
\end{tabular}

Sources: Norwegian National Election Studies (NNES), Panels 1997-2001, 2001-2005, 2005-2009, 20092013

Notes: Unstandardised regression coefficients; standard errors in parentheses.

${ }^{+} p<0.10,{ }^{*} p<0.05,{ }^{* *} p<0.01$

${ }^{8}$ 1997-2001, 2001-2005, 2005-2009, 2009-2013. 
The results presented in Table 1 show that in the three panels covering the period 1997-2009, FrP supporters became less satisfied with democracy between the two time-points of each panel relative to supporters of the largest party, Labour (the reference category). These negative effects are all sizable and significant. Thus, this analysis corroborates previous research in that supporters of FrP displayed a negative satisfaction-dynamic typical of populist right-wing supporters outside of government (Hooghe and Dassonneville 2016; Rooduijn, van der Brug and de Lange 2016). Furthermore, it is evident that the dynamics displayed by FrP supporters in this period are not commonplace in the Norwegian electorate. No other group of voters exhibits the same behaviour systematically.

Interestingly, this negative effect ceases in magnitude and becomes insignificant in the final panel that assesses changes from 2009 to 2013 , which is the period when the other-non-socialist parties eventually accepted FrP as a governing coalition partner. Could this change in dynamics has come about not as a result of FrP's inclusion into government, but simply because FrP increased their share of the votes in this period? Granted, this analysis does not allow for directly testing the specific mechanism underlying the satisfaction dynamics of the populist right. However, the result of the Norwegian parliamentary election in 2013 suggests that government inclusion indeed is a key factor. In this election, the Progress Party lost more than six percent of the vote share compared to the result of the previous national election in 2009 (22.9 percent of the vote share in 2009 vs. 16.3 percent in 2013). In other words, the negative satisfaction dynamic of the populist right (compared to Labur) ceases in magnitude and 
becomes insignificant in a period when FrP's vote share decreses, but enters a governing coalition for the first time. ${ }^{9}$

Post-estimations showed that these results are not driven by the choice of reference category. The same substantive results are obtained when the change rates of populist right-wing supporters are compared to the mean changes of non-populist supporters (grand mean comparisons). ${ }^{10}$ Moreover, they do not change when the models are estimated using an ordinal logistic regression. ${ }^{11}$ However, these results should not be interpreted to mean that supporters of the populist right necessarily decreased their satisfaction with democracy in absolute terms between the two time points of each panel covering the 1997-2009 period. Rather, the descriptive statistics show that the negative effects are driven by the combination of other voters increasing their satisfaction level at the same time as supporters of the Progress Party display stable low levels; however, in the final panel (2009-2013), there is a general (absolute) increase in satisfaction with democracy in the electorate that also pertains to supporters of the Progress Party. ${ }^{12}$

In summary, these results portray Norway as an overall consensual political system characterised by stable levels of political support; however, they also shed light on the dynamics underneath the party-level trajectories previously revealed by the ESS data. That is, supporters of the populist right become increasingly dissatisfied with democracy relative to other voters. Interestingly, this development ceased when FrP

\footnotetext{
${ }^{9}$ See Table A3 and Table A4 in the appendix for background information regarding party size and government formations for recent Norwegian national elections.

${ }^{10}$ See Table A5 in the appendix.

${ }^{11}$ See Table A6 in the appendix

${ }^{12}$ See Table A7 in the appendix for descriptive statistics.
} 
eventually became accepted as a viable coalition partner and joined a coalition government in 2013. In the next section, the way their satisfaction with democracy develops in the long-term after their party has assumed office is explored.

\section{Individual level dynamics when in office}

In this final analysis, the NCP data were used to investigate the development of populist right-wing supporters' satisfaction with democracy in Norway throughout the period of 2013-2016. Unfortunately, the data do not contain any observations before FrP entered government office. This means they cannot shed light on the short-term boost in satisfaction expected given the developments evident in the ESS data. Still, the NCP provides detailed insight into populist right-wing supporters' long-term development in satisfaction during a period when their party of choice was in office. Thus, these analyses facilitate a test of hypotheses H1B. The results from a series of latent growth models are presented in Table 2. 
Table 2. Explaining satisfaction with democracy (1-5). Latent growth models.

\begin{tabular}{|c|c|c|c|c|c|}
\hline & & $\begin{array}{c}\text { Model } 1 \\
\text { Unconditional } \\
\text { growth }\end{array}$ & $\begin{array}{c}\text { Model } 2 \\
\text { Dynamic party } \\
\text { preference }\end{array}$ & $\begin{array}{c}\text { Model } 3 \\
\text { Dynamic party } \\
\text { preference } \\
\text { with controls }\end{array}$ & $\begin{array}{c}\text { Model } 4 \\
\text { Fixed party } \\
\text { preference }\left(\mathrm{t}_{1}\right) \\
\text { with controls }\end{array}$ \\
\hline \multicolumn{6}{|l|}{ Fixed effects } \\
\hline \multirow[t]{32}{*}{ Initial status } & Intercept & $3.921^{* *}$ & $4.073^{* *}$ & $3.357^{* *}$ & $3.582^{* *}$ \\
\hline & & $(0.013)$ & $(0.026)$ & $(0.051)$ & $(0.067)$ \\
\hline & Party preference (ref: AP) & & & & \\
\hline & $\mathrm{R} \emptyset \mathrm{dt}$ & & $-0.207^{*}$ & $-0.222^{*}$ & $-0.296^{*}$ \\
\hline & & & $(0.099)$ & $(0.101)$ & $(0.131)$ \\
\hline & SV & & -0.031 & -0.022 & 0.052 \\
\hline & & & $(0.068)$ & $(0.072)$ & $(0.086)$ \\
\hline & SP & & -0.087 & -0.110 & $-0.267^{* *}$ \\
\hline & & & $(0.076)$ & $(0.072)$ & $(0.078)$ \\
\hline & Krf & & -0.036 & $-0.113^{*}$ & $-0.300^{* *}$ \\
\hline & & & $(0.042)$ & $(0.045)$ & $(0.095)$ \\
\hline & $\mathrm{V}$ & & $-0.105^{+}$ & $-0.206^{* *}$ & $-0.286^{* * *}$ \\
\hline & & & $(0.058)$ & $(0.061)$ & $(0.071)$ \\
\hline & $\mathrm{H}$ & & $-0.188^{* *}$ & $-0.441^{* * *}$ & $-0.394^{* *}$ \\
\hline & & & $(0.037)$ & $(0.042)$ & $(0.045)$ \\
\hline & FrP & & $-0.233^{* *}$ & $-0.476^{* *}$ & $-0.800^{* * *}$ \\
\hline & & & $(0.043)$ & $(0.048)$ & $(0.057)$ \\
\hline & MDG & & $-0.273^{* *}$ & $-0.339^{* *}$ & $-0.489^{* *}$ \\
\hline & & & $(0.084)$ & $(0.089)$ & $(0.123)$ \\
\hline & No party preference & & $-0.531^{* *}$ & $-0.616^{* *}$ & $-1.004^{* *}$ \\
\hline & & & $(0.114)$ & $(0.115)$ & $(0.190)$ \\
\hline & Lower educated (ref: middle) & & & $-0.058^{*}$ & $-0.076^{*}$ \\
\hline & & & & $(0.027)$ & $(0.037)$ \\
\hline & Higher educated (ref: middle) & & & $0.139^{* *}$ & $0.119^{* *}$ \\
\hline & & & & $(0.019)$ & $(0.028)$ \\
\hline & Age (categorical, 7 categories) & & & $0.015^{* *}$ & $0.024^{* *}$ \\
\hline & & & & $(0.005)$ & $(0.008)$ \\
\hline & Female (ref: male) & & & $0.094^{* *}$ & 0.026 \\
\hline & & & & $(0.017)$ & $(0.024)$ \\
\hline & Satisfaction with government & & & $0.213^{* *}$ & $0.172^{* *}$ \\
\hline & (categorical, 5 categories) & & & & \\
\hline & & & & $(0.011)$ & $(0.014)$ \\
\hline \multirow[t]{21}{*}{ Change rates } & Intercept & $-0.057^{* *}$ & $-0.070^{* *}$ & $-0.087^{* *}$ & $-0.089^{* * *}$ \\
\hline & & $(0.003)$ & $(0.006)$ & $(0.006)$ & $(0.007)$ \\
\hline & Party preference (ref: AP) & & & & \\
\hline & $\mathrm{R} \varnothing \mathrm{dt}$ & & $-0.039^{+}$ & -0.024 & -0.022 \\
\hline & & & $(0.022)$ & $(0.022)$ & $(0.029)$ \\
\hline & SV & & -0.005 & 0.005 & -0.014 \\
\hline & & & $(0.016)$ & $(0.016)$ & $(0.019)$ \\
\hline & SP & & $-0.027^{+}$ & -0.024 & 0.011 \\
\hline & & & $(0.016)$ & $(0.015)$ & $(0.017)$ \\
\hline & Krf & & 0.005 & -0.003 & $0.052^{* *}$ \\
\hline & & & $(0.014)$ & $(0.014)$ & $(0.020)$ \\
\hline & $\mathrm{V}$ & & $0.038^{*}$ & $0.039^{*}$ & $0.063^{* *}$ \\
\hline & & & $(0.017)$ & $(0.016)$ & $(0.015)$ \\
\hline & $\mathrm{H}$ & & $0.032^{* * *}$ & $0.039^{* *}$ & $0.036^{* *}$ \\
\hline & & & $(0.008)$ & $(0.009)$ & $(0.010)$ \\
\hline & FrP & & $0.025^{*}$ & $0.031^{* *}$ & $0.026^{*}$ \\
\hline & & & $(0.010)$ & $(0.010)$ & $(0.012)$ \\
\hline & MDG & & 0.019 & $0.037^{+}$ & $0.058^{*}$ \\
\hline & & & $(0.019)$ & $(0.020)$ & $(0.026)$ \\
\hline & No party preference & & 0.035 & $0.045^{+}$ & 0.045 \\
\hline & & & $(0.026)$ & $(0.027)$ & $(0.037)$ \\
\hline \multicolumn{6}{|c|}{ Variance components } \\
\hline \multirow[t]{2}{*}{ Level 1} & Within-person & $0.237^{* *}$ & $0.235^{* *}$ & $0.227^{* *}$ & $0.236^{* *}$ \\
\hline & & $(0.006)$ & $(0.006)$ & $(0.006)$ & $(0.009)$ \\
\hline \multirow{6}{*}{ Level 2} & In initial status & $0.533^{* *}$ & $0.483^{* *}$ & $0.483^{* *}$ & $0.318^{* *}$ \\
\hline & & $(0.024)$ & $(0.029)$ & $(0.028)$ & $(0.018)$ \\
\hline & In rate of change & $0.018^{* * *}$ & $0.017^{* * *}$ & $0.016^{* *}$ & $0.011^{* *}$ \\
\hline & & $(0.001)$ & $(0.001)$ & $(0.001)$ & $(0.001)$ \\
\hline & Covariance & $-0.569^{* *}$ & $-0.588^{* * *}$ & $-0.673^{* *}$ & $-0.437^{* *}$ \\
\hline & & $(0.034)$ & $(0.044)$ & $(0.042)$ & $(0.044)$ \\
\hline Goodness-of-fit & Log lik. & -25571.098 & -20971.065 & -19494.213 & -10332.197 \\
\hline \multirow[t]{3}{*}{$\mathrm{N}$} & Observations & 36309 & 28558 & 27200 & 16652 \\
\hline & Number of individuals & 10500 & 9281 & 8807 & 3890 \\
\hline & Waves & 7 & 7 & 7 & 7 \\
\hline
\end{tabular}

Sources: Norwegian Citizens Panel (NCP) 2013-2017 (seven waves). Notes: Unstandardised regression coefficients, standard errors in parentheses. ${ }^{+} p<0.10,{ }^{*} p<0.05,{ }^{* *} p<0.01$. The data is weighted by age, gender, region and education. 
Model 1 provides a first glimpse of the dynamics of satisfaction with democracy. This is a so-called 'unconditional growth' model in which time is included as the only predictor. The negative change rate coefficient in this model $(-0.057)$ indicates that there was a moderate overall decline in satisfaction from autumn 2013 to autumn 2016 in the Norwegian electorate. To what extent do the supporters of the populist right drive this development?

To answer this question, in model 2, party preferences were introduced as explanatory variables. As discussed in the methodology section, latent growth models partition the variation in the dependent variable in two parts, providing two sets of coefficients. The 'initial status' coefficients reported in the upper half of the table are level two variables and explain inter-individual variation. Specifically, they show the level of satisfaction with democracy among different voter groups approximately two months after the Norwegian parliamentary election in 2013 (the first time point in the data). The 'change rate' coefficients reported in the lower half of the table are level one variables and show intra-individual variation. Specifically, they indicate at what rate and in what direction satisfaction with democracy changed for each group of voters for each time point throughout the panel (one survey-wave is one time point) relative to supporters of the largest party, Labour (the reference category).

Beginning with the initial status coefficients, even though FrP had just won the election, its supporters are the least satisfied group at the first time point (-.0.233) (besides supporters of the minor environmental party [MDG] and those without a reported party preference). However, the difference between their satisfaction level and the satisfaction of supporters of their coalition partner, the conservative party (Høyre) ($.188)$, is modest. As every initial status coefficient in this model is negative, supporters of Labour (the reference category) were the most satisfied group at this time point. 
Moving to the change rate coefficients that show the changes in satisfaction over time, the model suggests that the initial gap in satisfaction between supporters of the populist right and supporters of Labour (the reference category) is reduced throughout the electoral cycle. In other words, relative to the development of the major opposition party, FrP supporters increased their satisfaction with democracy over time. The size of the change rate coefficient (.025) suggests that the initial difference in satisfaction indicated by the 'initial status' coefficient (-0.233) will disappear after approximately five years in government (10 periods). Still, because the (negative) change rate coefficient of Labour (reference category) is stronger than the (positive) change rate coefficient of FrP, in absolute terms, FrP supporters displayed a negative development in satisfaction as well. 
Figure 3. Predicted satisfaction with democracy, NCP

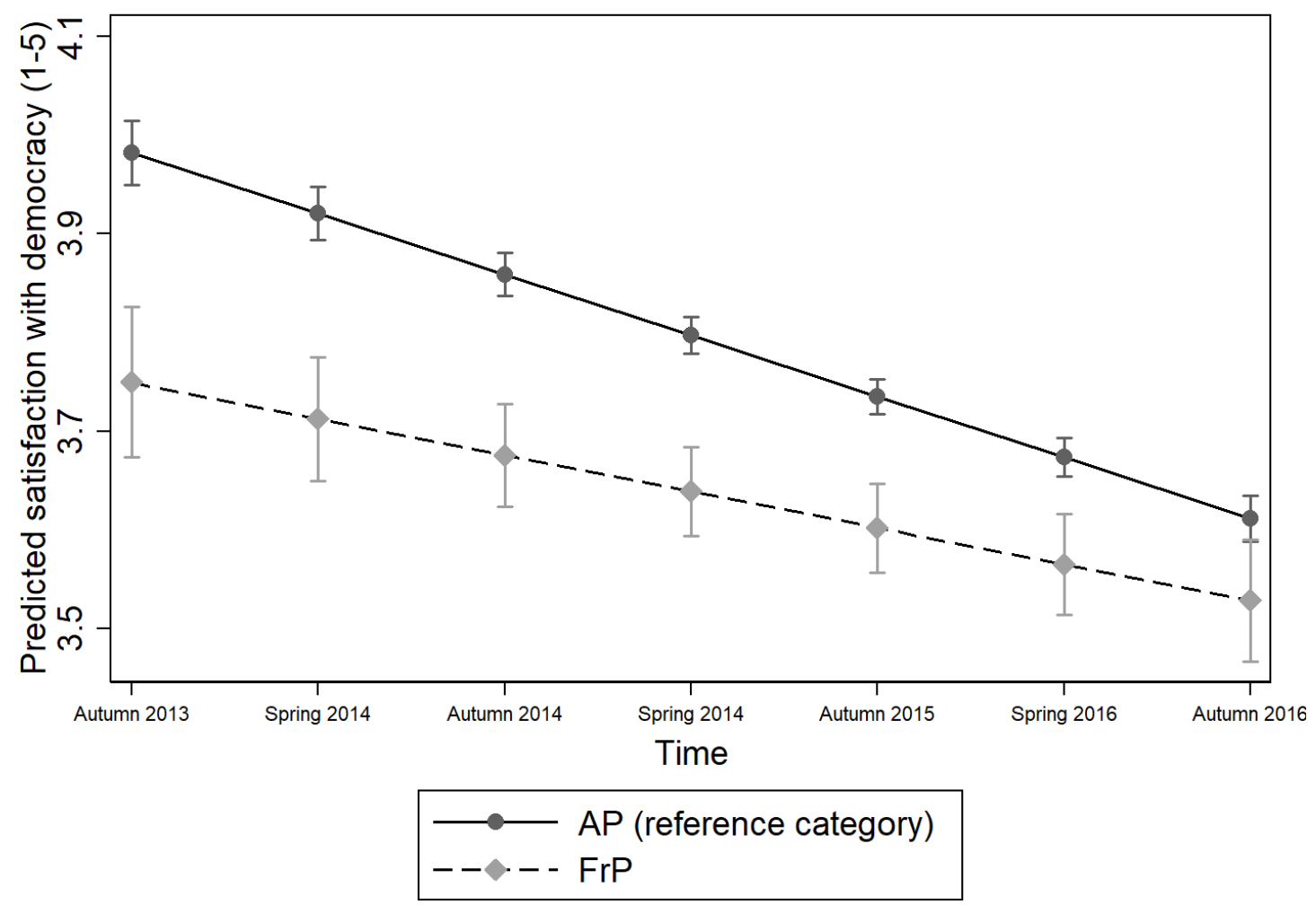

Note: Predicted values from model 2 in Table 3.

For ease of interpretation, the predicted levels of satisfaction with democracy throughout the panel are illustrated in Figure $3 .{ }^{13}$ As the figure illustrates, both supporters of the Progress Party and supporters of Labour became increasingly dissatisfied with democracy; however, because FrP supporters had the least steep decline, the satisfaction gap decreased over time. Additional post-estimations show that the trajectory of FrP supporters was not significantly different from that of supporters of

${ }^{13}$ As evident in Figure 3, the models reported in Table 2 assume that growth in satisfaction is linear. Descriptive statistics, however, show that most of the decline in satisfaction occurs between autumn 2015 and spring 2016. Thus, I have also estimated models with a discontinuous time variable. The results from these models are almost identical to the ones reported in Table 2 and can be retained upon request. 
their coalition partner, the conservative party (Høyre). In other words, supporters of the two parties in government experienced a parallel development in satisfaction in this period.

These results remained substantively the same when a number of control variables were introduced in model $3 .{ }^{14}$ Moreover, because changes in party preferences between elections are common, in model 4, a fixed rather than a dynamic party preference variable was used. That is, instead of analysing the effect of party preference at each time-point, a non-dynamic party preference variable fixed at the respondents' party preference at $\mathrm{t}_{1}$ was used. This analysis yielded generally the same results with respect to Frp supporters' development in satisfaction over time. The results are also substantively unaltered when similar models are estimated with multilevel ordinal logistic regression, ${ }^{15}$ and when the analyses are rerun by using multiple imputation. ${ }^{16}$ In other words, the developments illustrated in Figure 3 seem to be robust for several different modelling strategies.

\section{Discussion and conclusion}

Almost three decades ago, Miller and Listhaug (1990) famously argued that the presence of protest parties in multiparty systems allows dissatisfied voters to channel their political frustrations back into the legislative arena. They argued that this form of responsiveness can alleviate political distrust. Their study was conducted in the wake of the so-called 'third wave' of far right mobilisation in Europe when various populist

\footnotetext{
${ }^{14}$ I controlled for standard socioeconomic status variables as well as government satisfaction. The latter variable correlates with the dependent variable at 0.16 .

${ }^{15}$ See Table A8 in the appendix.

${ }^{16}$ See Table A9 in the appendix.
} 
right-wing parties had just passed Rokkan's (1970) third institutional threshold in his model of mobilisation - representation in parliament. However, a current pressing question regarding what happens when members of this party family surmount Rokkan's final institutional threshold — access to executive power-is still unclear. Will control of the central arena of decision making in liberal democracies incite these parties to moderate their populist rhetoric and boost satisfaction among their supporters, or will limited policy impacts and sustained populist messages even from within the government generate disappointment and therefore increase dissatisfaction with the political system?

The findings in this article collectively suggest that crossing Rokkan's (1970) final institutional threshold has positive effects on populist ring-wing supporters' satisfaction with democracy. The ESS data showed that supporters of the populist right in Norway did experience an immediate boost in satisfaction with democracy once their party assumed office for the first time. Furthermore, individual-level panel data showed that the gap in satisfaction between populist right-wing supporters and other voters has decreased in response to FrP's entrance into office for two different reasons. In the short-term, the gap was narrowed because populist right-wing supporters responded positively to the experience of winning an election. In the long-term, the gap decreased because supporters of other parties had a steeper decline in satisfaction than supporters of the populist right. In other words, FrP no longer served as the primary channel of dissatisfaction within the party system. It should, however, be noted that there are uncertainties involved for these observations. Most importantly, there was a lack of one consistent individual-panel data source that could capture both short- and long-term dynamics for the subject matter. 
Bearing this caveat in mind, two important implications seem to follow from the findings presented in this article. First, in line with previous research results on FPÖ in Austria (Bergh 2004), the overall results lend support to the moderation perspective rather than the radicalisation perspective. It should, however, be stressed that the attitudinal changes observed in the analyses supporting the moderation perspective only pertain to populist right-wing supporters' general attitudes towards the working of democracy. Other dynamics may occur with respect to these voters' policy attitudes. Recent research do show that voters who change their party preference to the populist right become more radicalised in their view of immigration (Harteveld, Kokkonen and Dahlberg 2017). It could very well be that this process is strengthened once the populist right gains executive power. In other words, even though the results in this article suggest that FrP voters would have become less satisfied with democracy without their party's entrance into government, executive power may also have made FrP voters more confident in their political views and, thus, radicalised with respect to attitudes towards immigration. This is an important question for future research.

A likely explanation for the findings presented in this article would be that the symbolic effect of winning an election immediately did boost populist right-wing supporters' satisfaction with democracy. Moreover, the demands of national office might have restrained the rhetoric of prominent members of the party, and, thus, weakened the 'fueling discontent' mechanism found in previous research (Rooduijn, van der Brug and de Lange 2016). However, although the gap in satisfaction between populist right-wing supporters and other voters has narrowed, the results also showed an absolute decrease in satisfaction with democracy among populist right-wing supporters in the period 2013-2016. This suggests that the persistence of the immediate boost may depend on other factors highlighted by the radicalisation perspective, such as the quality 
of the representation the party provides and the behaviours of their political leaders while in power.

Second, the findings indicate that the political integration of the populist right may not only affect their own supporters' satisfaction with democracy but may also have wider democratic ramifications. A particularly important question is how nonpopulists react to the political integration of this party family. Is there a trade-off in the sense that the integration of distrustful voters spurs disenchantment among those previously well-integrated? The evidence in this article does not provide an unequivocal answer to this question, but the overall long-term decline in satisfaction evident in the NCP driven by non-populists from 2013-2016 suggests that this might be the case. In any case, the way the integration of populist right-wing supporters affects the satisfaction of other groups is an important question for future research.

Finally, although the Norwegian experience with FrP's transition to power is indicative of broader political developments in contemporary European democracies, the findings presented in this paper are likely to be context-sensitive. As a point of departure for future research, I believe four factors are likely to play a role in explaining comparative variation: party systems' clarity of responsibility, the number of parties in government, populist right-wing parties' abilities to provide substantive representation to their supporters, and the behavior of populist politicians in power.

First, although the winner-loser gap in satisfaction with democracy is often assumed to be a general phenomenon, consensus-democracy is found to close the gap in satisfaction between electoral winners and losers (Anderson and Guillory 1997; Bernauer and Vatter 2012). Thus, the symbolic effect of winning an election might be even stronger in political systems with clearer lines of responsibility than the Norwegian multiparty system. A second factor relates to whether or not populists in 
government have to share power with a coalition partner. Coalition governments require compromises of all governing parties, and such collaboration may temper the populist profile of this party family. In other words, in cases where the populist right get power undivided, as is the case with Orban, Kaczynski of Trump, moderation effects might be less likely to occur. A third factor concerns populist right-wing parties' abilities to deliver substantive representation to their voters. Kriesi (2014:369) recently argued that populist parties are 'driving forces of processes of restructuration and realignment of the party system' because they politicise conflicts that established parties have neglected. Still, their ability to not only politicise but actually implement their policies depends on a number of factors, such as their relative size in government, the number and strength of checks in the political system (i.e. bureaucracies, non-governmental actors) and their ability to learn and adapt to the demands of office (Mudde 2013). These factors may in turn be crucial to their supporters' long-term satisfaction with democracy. A final question relates to the behaviours of their leaders when in office. To what extent will they continue to advocate anti-establishment messages with possible negative effects on the quality of democratic discourse? Both the broader political climate and the turnout at the polls will probably play a role. Perhaps a moderation effect is less likely to come about in countries with lower levels of political trust than Norway. An important task for future research is to examine these and other comparative hypotheses related to the democratic ramifications of the electoral rise of the populist right. 


\section{References}

Aardal, Bernt, and Johannes Bergh (Eds.). 2015. Valg og velgere. En studie av stortingsvalget 2013. Oslo: Cappelen Damm Akademisk.

Akkerman, Tjitske, Sarah L de Lange, and Matthijs Rooduijn. 2016a. "Inclusion and mainstreaming? Radical right-wing populist parties in the new millenium." Pp. 1-28 in Radical Wight-Wing Populist Parties in Western Europe. Into the Mainstream?, edited by Tjitske Akkerman, Sarah L de Lange, and Matthijs Rooduijn. Milton park: Routledge.

—. 2016b. "Into the mainstream? A comparative analysis of the programmatic profiles of radical right-wing populist parties in Western Europe over time." Pp. 31-52 in Radical Wight-Wing Populist Parties in Western Europe. Into the Mainstream?, edited by Tjitske Akkerman, Sarah L de Lange, and Matthijs Rooduijn. Milton Park: Routledge.

— (Eds.). 2016c. Radical Right-Wing Populist Parties in Western Europe: Into the Mainstream? Milton Park: Routledge.

Albertazzi, Daniele, and Duncan McDonnell. 2005. "The Lega Nord in the second Berlusconi government: In a league of its own." West European Politics 28(5):952-72.

—. 2010. "The Lega Nord Back in Government." West European Politics 33(6):131840.

Allern, Elin Haugsgjerd. 2010. "Survival of a majority coalition: The Norwegian parliamentary election of 14 September 2009." West European Politics 33(4):904-12.

Allern, Elin Haugsgjerd, and Rune Karlsen. 2014. "A Turn to the Right: The Norwegian Parliamentary Election of September 2013." West European Politics 37(3):65363.

Anderson, Christopher J., André Blais, Shaun Bowler, Todd Donovan, and Ola Listhaug. 2005. Losers' Consent: Elections and Democratic Legitimacy. Oxford: Oxford University Press.

Anderson, Christopher J., and Christine A. Guillory. 1997. "Political Institutions and Satisfaction with Democracy: A Cross-National Analysis of Consensus and Majoritarian Systems." The American Political Science Review 91(1):66-81. 
Bélanger, Éric. 2017. "Political trust and voting behaviour." Pp. 242-55 in Handbook on Political Trust, edited by Sonja Zmerli and T. W. G. Van der Meer. Chelternham: Edward Elgar Publishing.

Bélanger, Éric, and Kees Aarts. 2006. "Explaining the rise of the LPF: issues, discontent, and the 2002 Dutch election." Acta politica 41(1):4-20.

Bélanger, Éric, and Richard Nadeau. 2005. "Political Trust and the Vote in Multiparty Elections: The Canadian Case." European Journal of Political Research 44(1):121-46.

Bengtsson, Åsa, Kasper Hansen, Ólafur P Harõarson, Hanne Marthe Narud, and Henrik Oscarsson. 2014. The Nordic Voter: Myths of Exceptionalism. London, UK: ECPR Press.

Bergh, Johannes. 2004. "Protest Voting in Austria, Denmark, and Norway." Scandinavian Political Studies 27(4):367-89.

Bernauer, Julian, and Adrian Vatter. 2012. "Can't get no satisfaction with the Westminster model? Winners, losers and the effects of consensual and direct democratic institutions on satisfaction with democracy." European Journal of Political Research 51(4):435-68.

Bjånesøy, Lise Lund, and Elisabeth Ivarsflaten. 2016. "What Kind of Challenge? RightWing Populism in Contemporary Western Europe." Pp. 33-50 in Democratic Transformations in Europe: Challenges and Opportunities, edited by Yvette Peters and Michaël Tatham. London and New York: Routledge.

Canache, Damarys, Jeffery J. Mondak, and Mitchell A. Seligson. 2001. "Meaning and Measurement in Cross-National Research on Satisfaction with Democracy." Public Opinion Quarterly 65(4):506-28.

Citrin, Jack. 1974. "Comment: The Political Relevance of Trust in Government." The American Political Science Review 68(3):973-88.

Curini, Luigi, Willy Jou, and Vincenzo Memoli. 2012. "Satisfaction with Democracy and the Winner/Loser Debate: The Role of Policy Preferences and Past Experience." British Journal of Political Science 42(02):241-61.

Dahlberg, Stefan, and Jonas Linde. 2016. "The dynamics of the winner-loser gap in satisfaction with democracy: Evidence from a Swedish citizen panel." International Political Science Review 38(5):625-41. 
Deschouwer, Kris. 2008. "Comparing newly governing parties." Pp. 1-16 in New Parties in Government. In power for the first time, edited by Kris Deschouwer. London and New York: Routledge/ECPR Studies in European Political Science.

Fangen, Katrine, and Mari N Vaage. 2015. "FrP-politikeres innvandringsretorikk i posisjon og opposisjon." Agora 31(03-04):30-63.

Finkel, Steven E. 1995. Causal analysis with panel data. Thousand Oaks, CA: Sage. Harteveld, Eelco, Andrej Kokkonen, and Stefan Dahlberg. 2017. "Adapting to party lines: the effect of party affiliation on attitudes to immigration." West European Politics 40(6):1177-97.

Hetherington, Marc J. 1999. "The Effect of Political Trust on the Presidential Vote, 1968-96." The American Political Science Review 93(2):311-26.

Hooghe, Marc. 2018. "Trust and Elections." Pp. 617-362 in The Oxford Handbook of Social and Political Trust, edited by Eric M Uslaner. New York, NY: Oxford University Press.

Hooghe, Marc, and Ruth Dassonneville. 2016. "A Spiral of Distrust: A Panel Study on the Relation between Political Distrust and Protest Voting in Belgium." Government and Opposition 53(1):104-30.

Hooghe, Marc, and Dieter Stiers. 2016. "Elections as a democratic linkage mechanism: How elections boost political trust in a proportional system." Electoral Studies 44:46-55.

Ivarsflaten, Elisabeth. 2008. "What Unites Right-Wing Populists in Western Europe?" Comparative Political Studies 41(1):3-23.

—. 2017. "Norsk medborgerpanel runde 1-7 kombinert, 2013-2016. Universitetet i Bergen." Første NSD-utgave, Bergen.

Jupskås, Anders Ravik. 2015. The persistence of populism. The Norwegian progress party 1973-2009. Oslo: Univeristy of Oslo.

—. 2016. "The taming of the shrew." Pp. 169-92 in Radical Right-Wing Populist Parties in Western Europe: Into the Mainstream?, edited by Tjitske Akkerman, Sarah L De Lange, and Matthijs Rooduijn. Milton park: Routledge.

Kriesi, Hanspeter. 2014. "The populist challenge." West European Politics 37(2):36178.

Lenz, Gabriel S. 2012. Follow the Leader? How Voters Respond to Politicians' Policies and Performance. Chicago, IL: The University of Chicago Press. 
Linde, Jonas, and Stefan Dahlberg. 2016. "Democratic Discontent in Times of Crisis?" Pp. 72-95 in Democratic Transformations in Europe: Challenges and Prospects, edited by Yvette Peters and Michaël Tatham. London and New York: Routledge.

Linde, Jonas, and Joakim Ekman. 2003. "Satisfaction with Democracy: A Note on a Frequently Used Indicator in Comparative Politics." European Journal of Political Research 42(3):391-408.

Luther, Kurt Richard. 2011. "Of goals and own goals: A case study of right-wing populist party strategy for and during incumbency." Party Politics 17(4):453-70.

McDonnell, Duncan, and James L. Newell. 2011. "Outsider parties in government in Western Europe." Party Politics 17(4):443-52.

Miller, Arthur H., and Ola Listhaug. 1990. "Political Parties and Confidence in Government: A Comparison of Norway, Sweden and the United States." British Journal of Political Science 20(03):357-86.

Mudde, C. A. S. 2013. "Three decades of populist radical right parties in Western Europe: So what?" European Journal of Political Research 52(1):1-19.

Mudde, Cas. 2007. Populist Radical Right Parties in Europe. Cambridge: Cambridge University Press.

Newton, Kenneth. 2008. "Trust and Politics." Pp. 241-72 in The handbook of social capital, edited by D. Castiglione, Jan W. Van Deth, and G. Wolleb. Oxford: Oxford University Press.

Norris, Pippa. 2011. Democratic Deficit: Critical Citizens Revisited. Cambridge: Cambridge University Press.

Plutzer, Eric. 2002. "Becoming a habitual voter: Inertia, resources, and growth in young adulthood." American Political Science Review 96(1):41-56.

Rokkan, Stein. 1970. Citizens, elections, parties: Approaches to the comparative study of political development. Oslo: Universitetsforlaget.

Rooduijn, Matthijs, Wouter van der Brug, and Sarah L de Lange. 2016. "Expressing or fuelling discontent? The relationship between populist voting and political discontent." Electoral Studies 43:32-40.

Singer, Judith D., and John B. Willett. 2003. Applied Longitudinal Data Analysis. Applied Longitudinal Data Analysis. New York: Oxford University Press. 
Torcal, Mariano. 2017. "Political trust in Western and Southern Europe." Pp. 418-39 in Handbook on Political Trust, edited by Sonja Zmerli and T. W. G. Van der Meer. Cheltenham, UK: Edward Elgar Publishing.

Van der Brug, Wouter. 2003. "How the LPF fuelled discontent: Empirical tests of explanations of LPF support." Acta politica 38(1):89-106.

Van der Brug, Wouter, Meindert Fennema, and Jean Tillie. 2005. "Why some antiimmigrant parties fail and others succeed A two-step model of aggregate electoral support." Comparative Political Studies 38(5):537-73.

van Ham, Carolien, Jacques Thomassen, Kees Aarts, and Rudy Andeweg (Eds.). 2017. Myth and Reality of the Legitimacy Crisis: Explaining Trends and Crossnational Differences in Established Democracies. Oxford: Oxford University Press. 


\section{Appendix}

\section{Tables}

A1. Mean levels of satisfaction with democracy in Norway 2002-2016

A2. Cross-sectional OLS regression of satisfaction with democracy

A3. Results of Norwegian parliamentary elections 1997-2017

A4. Government formations in Norway 1997-2017

A5. Grand mean comparisons: Fremskrittspartiet (FRP) vs. mean

A6. Explaining $\Delta$ Satisfaction with Democracy 1997-2013, Ordinal logistic regression

A7. Descriptive statistics satisfaction with democracy, NNES panels 97-13

A8. Explaining satisfaction with democracy, Ordinal logistic latent growth models

A9. Explaining satisfaction with democracy using multiple imputation, Latent growth models

\section{Figures}

A1. Mean satisfaction with democracy by country in Europe (0-10) 
Table A1. Mean levels of satisfaction with democracy (0-10) 2002-2016, ESS

\begin{tabular}{c|ll|ll}
\hline & \multicolumn{2}{|c|}{ FrP } & \multicolumn{2}{c}{ Non-FrP } \\
\hline Year & Mean & Std.Err & Mean & Std.Err \\
\hline 2002 & 5,42 & 0,15 & 6,44 & 0,07 \\
2004 & 5,55 & 0,16 & 6,53 & 0,07 \\
2006 & 5,58 & 0,16 & 7,01 & 0,06 \\
2008 & 5,58 & 0,18 & 6,99 & 0,08 \\
2010 & 5,91 & 0,20 & 7,31 & 0,06 \\
2012 & 5,56 & 0,20 & 7,46 & 0,05 \\
2014 & 6,75 & 0,22 & 7,47 & 0,06 \\
2016 & 6,35 & 0,22 & 7,43 & 0,06 \\
\hline
\end{tabular}


Table A2. Cross-sectional OLS regression of satisfaction with democracy, ESS

\begin{tabular}{|c|c|c|c|c|c|c|c|c|}
\hline & 2002 & 2004 & 2006 & 2008 & 2010 & 2012 & 2014 & 2016 \\
\hline \multirow{2}{*}{ Years of education (cont.) } & $0.07^{* *}$ & $0.07^{* *}$ & $0.04^{*}$ & $0.08^{* *}$ & -0.01 & 0.01 & 0.02 & $0.03^{*}$ \\
\hline & $(0.02)$ & $(0.02)$ & $(0.02)$ & $(0.02)$ & $(0.02)$ & $(0.01)$ & $(0.01)$ & $(0.02)$ \\
\hline \multirow[t]{2}{*}{ Age (cont.) } & 0.00 & 0.01 & 0.00 & 0.00 & -0.01 & 0.00 & $-0.01^{*}$ & $-0.01^{*}$ \\
\hline & $(0.00)$ & $(0.00)$ & $(0.00)$ & $(0.00)$ & $(0.00)$ & $(0.00)$ & $(0.00)$ & $(0.00)$ \\
\hline \multirow[t]{2}{*}{ Female $(0-1)$} & $-0.25^{*}$ & $-0.35^{* *}$ & -0.00 & -0.23 & -0.06 & 0.09 & -0.09 & -0.05 \\
\hline & $(0.13)$ & $(0.12)$ & $(0.12)$ & $(0.14)$ & $(0.13)$ & $(0.11)$ & $(0.12)$ & $(0.12)$ \\
\hline \multirow[t]{2}{*}{ Unemployed (0-1) } & -0.21 & -0.70 & -0.46 & 0.78 & -0.03 & -0.62 & 0.41 & -0.45 \\
\hline & $(0.40)$ & $(0.39)$ & $(0.60)$ & $(0.44)$ & $(0.42)$ & $(0.50)$ & $(0.48)$ & $(0.42)$ \\
\hline \multirow{2}{*}{$\begin{array}{l}\text { Subjective income } \\
\text { (categorical, } 4 \text { categories) }\end{array}$} & $-0.31^{* *}$ & $-0.31^{* *}$ & $-0.21^{*}$ & $-0.28^{*}$ & -0.10 & -0.16 & $-0.27^{*}$ & $-0.23^{*}$ \\
\hline & $(0.11)$ & $(0.09)$ & $(0.10)$ & $(0.13)$ & $(0.11)$ & $(0.10)$ & $(0.12)$ & $(0.11)$ \\
\hline \multirow{2}{*}{$\begin{array}{l}\text { Populist right-wing support } \\
(0-1)\end{array}$} & $-0.88^{* *}$ & $-0.88^{* *}$ & $-1.36^{* *}$ & $-1.25^{* *}$ & $-1.43^{* *}$ & $-1.83^{* *}$ & $-0.64^{* *}$ & $-1.04^{* * *}$ \\
\hline & $(0.18)$ & $(0.18)$ & $(0.17)$ & $(0.21)$ & $(0.22)$ & $(0.22)$ & $(0.23)$ & $(0.23)$ \\
\hline \multirow[t]{2}{*}{ Intercept } & $6.12^{* * *}$ & $6.32^{* *}$ & $6.74^{* *}$ & $6.63^{* *}$ & $7.94^{* * *}$ & $7.38^{* *}$ & $8.09^{* *}$ & $7.68^{* * *}$ \\
\hline & $(0.51)$ & $(0.46)$ & $(0.40)$ & $(0.66)$ & $(0.40)$ & $(0.32)$ & $(0.41)$ & $(0.44)$ \\
\hline$N$ & 1141 & 1062 & 1038 & 975 & 919 & 1006 & 886 & 970 \\
\hline$R^{2}$ & 0.082 & 0.084 & 0.108 & 0.121 & 0.085 & 0.132 & 0.036 & 0.056 \\
\hline
\end{tabular}

Standard errors in parentheses

${ }^{*} p<0.05,{ }^{* *} p<0.01$ 
Table A3. Results of Norwegian parliamentary elections 1997-2017

\begin{tabular}{lllllll}
\hline Party & 1997 & 2001 & 2005 & 2009 & 2013 & 2017 \\
\hline RV/Rødt & 1,7 & 1,2 & 1,2 & 1,3 & 1,1 & 2,4 \\
SV & 6,0 & 12,5 & 8,8 & 6,2 & 4,1 & 6,0 \\
AP & 35,0 & 24,3 & 32,7 & 35,4 & 30,8 & 27,4 \\
V & 4,5 & 3,9 & 5,9 & 3,9 & 5,2 & 4,4 \\
KrF & 13,7 & 12,4 & 6,8 & 5,5 & 5,6 & 4,2 \\
SP & 7,9 & 5,6 & 6,5 & 6,2 & 5,5 & 10,3 \\
H & 14,3 & 21,2 & 14,1 & 17,2 & 26,8 & 25,0 \\
FrP & 15,3 & 14,6 & 22,1 & 22,9 & 16,3 & 15,2 \\
MDG & 0,2 & 0,2 & 0,1 & 0,3 & 2,8 & 3,2 \\
\hline
\end{tabular}

\section{Abbreviations}

RV/Rødt: Rød Valgallianse; from 2009: Rødt (Red Party)

SV: Sosialistisk Venstreparti (Socialist Left Party)

AP: Det norske Arbeiderparti (Labour Party)

V: Venstre (Liberal Party)

KrF: Kristelig Folkeparti (Christian Democratic Party)

SP: Senterpartiet (Centre Party)

H: Høyre (Conservative Party)

FrP: Fremskrittspartiet (Progress Party)

MDG: Miljøpartiet De Grønne (Green Party) 
Table A4. Government formations in Norway 1997-2017

\begin{tabular}{lll}
\hline Period & Prime minister & Party/parties in government \\
\hline October 1997 - March 2000 & Kjell Magne Bondevik & KrF, Sp, V \\
& $(\mathrm{KrF})$ & \\
Mars 2000 - October 2001 & Jens Stoltenberg (AP) & AP \\
October 2001 - October 2005 & Kjell Magne Bondevik & KrF, H, V \\
& $(\mathrm{KrF})$ & \\
October 2005 - October 2013 & Jens Stoltenberg (AP) & AP, SV, Sp \\
October 2013 - & Erna Solberg (H) & H, FrP (and V from January \\
& & 2018) \\
\hline
\end{tabular}


Table A5. Grand mean comparisons: Fremskrittspartiet (FRP) vs. mean

\begin{tabular}{ll}
\hline Period & Grand mean comparison \\
\hline $1997-2001$ & $-0.15^{*}(0.06)$ \\
$2001-2005$ & $-0.19^{* *}(0.00)$ \\
$2005-2009$ & $-0.09^{+}(0.06)$ \\
$2009-2013$ & $-0.01(0.07)$
\end{tabular}

Notes: Post-estimations from the analyses presented in Table 1. Grand mean comparisons computed with the command 'contrast' in Stata. Standard errors in parentheses.

Sources: Norwegian National Election Studies (NNES), Panels 1997-2001, 2001-2005, 2005-2009, 20092013.

${ }^{+} p<0.10,{ }^{*} p<0.05,{ }^{* *} p<0.01$ 
Table A6. Explaining $\Delta$ Satisfaction with Democracy 1997-2013, Ordinal logistic regression

\begin{tabular}{|c|c|c|c|c|}
\hline & $\begin{array}{c}1997- \\
2001\end{array}$ & $\begin{array}{l}2001- \\
2005\end{array}$ & $\begin{array}{l}2005- \\
2009\end{array}$ & $\begin{array}{c}2009- \\
2013\end{array}$ \\
\hline \multirow[t]{2}{*}{ Satisfaction with democracy $\mathrm{t}_{1}$} & $1.27^{* *}$ & $0.92^{* *}$ & $1.16^{* *}$ & $1.38^{* *}$ \\
\hline & $(0.15)$ & $(0.15)$ & $(0.16)$ & $(0.18)$ \\
\hline \multirow[t]{2}{*}{ Lower educated (ref: middle) $t_{1}$} & -0.28 & -0.16 & -0.34 & -0.52 \\
\hline & $(0.27)$ & $(0.28)$ & $(0.30)$ & $(0.34)$ \\
\hline \multirow[t]{2}{*}{ Higher educated (ref: middle) $t_{1}$} & 0.30 & -0.01 & -0.12 & 0.34 \\
\hline & $(0.20)$ & $(0.19)$ & $(0.19)$ & $(0.21)$ \\
\hline \multirow[t]{2}{*}{ Age (cont.) } & 0.00 & -0.00 & -0.00 & 0.01 \\
\hline & $(0.01)$ & $(0.01)$ & $(0.01)$ & $(0.01)$ \\
\hline \multirow[t]{2}{*}{ Female (ref: male) } & 0.05 & -0.20 & 0.20 & 0.19 \\
\hline & $(0.17)$ & $(0.18)$ & $(0.17)$ & $(0.19)$ \\
\hline \multicolumn{5}{|l|}{ Party voted for $\mathrm{t}_{1}$ (ref: AP) } \\
\hline \multirow[t]{2}{*}{$\mathrm{R} ø \mathrm{dt} / \mathrm{RV}$} & -0.54 & -0.86 & -0.46 & $-1.78^{*}$ \\
\hline & $(0.57)$ & $(0.74)$ & $(0.65)$ & $(0.86)$ \\
\hline \multirow[t]{2}{*}{ SV } & -0.08 & -0.34 & -0.13 & 0.06 \\
\hline & $(0.34)$ & $(0.28)$ & $(0.30)$ & $(0.39)$ \\
\hline \multirow[t]{2}{*}{$\mathrm{SP}$} & -0.18 & -0.18 & -0.19 & -0.04 \\
\hline & $(0.30)$ & $(0.39)$ & $(0.32)$ & $(0.37)$ \\
\hline \multirow[t]{2}{*}{$\mathrm{KrF}$} & -0.21 & -0.47 & $-1.02^{* *}$ & 0.07 \\
\hline & $(0.26)$ & $(0.31)$ & $(0.38)$ & $(0.51)$ \\
\hline \multirow[t]{2}{*}{ V } & 0.31 & -0.61 & -0.09 & -0.02 \\
\hline & $(0.40)$ & $(0.47)$ & $(0.36)$ & $(0.41)$ \\
\hline \multirow[t]{2}{*}{$\mathrm{H}$} & 0.38 & $-0.72^{* *}$ & $-0.47^{+}$ & 0.11 \\
\hline & $(0.27)$ & $(0.25)$ & $(0.27)$ & $(0.28)$ \\
\hline \multirow[t]{2}{*}{ FrP } & $-0.53^{+}$ & $-1.28^{* *}$ & $-0.64^{*}$ & -0.22 \\
\hline & $(0.29)$ & $(0.35)$ & $(0.26)$ & $(0.29)$ \\
\hline \multirow[t]{2}{*}{ Cut off 1} & -0.35 & $-2.96^{* * *}$ & -1.12 & -0.64 \\
\hline & $(0.69)$ & $(0.73)$ & $(0.72)$ & $(0.89)$ \\
\hline \multirow[t]{2}{*}{ Cut off 2} & $2.50^{* *}$ & -0.48 & 1.02 & $1.90^{* * *}$ \\
\hline & $(0.64)$ & $(0.65)$ & $(0.66)$ & $(0.73)$ \\
\hline \multirow[t]{2}{*}{ Cut off 3} & $6.21^{* *}$ & $3.53^{* *}$ & $4.81^{* * *}$ & $5.91^{* *}$ \\
\hline & $(0.69)$ & $(0.67)$ & $(0.69)$ & $(0.77)$ \\
\hline$N$ & 644 & 664 & 644 & 508 \\
\hline
\end{tabular}


A7. Descriptive statistics satisfaction with democracy (1-4), NNES panels 97-13

\begin{tabular}{ll|lllllll}
\hline Panel & Year & SV & AP & V & KrF & SP & H & FrP \\
\hline $1997-2001$ & 1997 & 3,18 & 3,30 & 3,33 & 3,26 & 3,15 & 3,29 & 3,05 \\
& 2001 & 2,96 & 2,98 & 3,09 & 2,90 & 2,88 & 3,09 & 2,71 \\
\hline \multirow{2}{2}{$2001-2005$} & 2001 & 2,88 & 3,05 & 3,15 & 3,05 & 2,85 & 2,95 & 2,55 \\
& 2005 & 3,07 & 3,19 & 3,07 & 3,06 & 3,13 & 2,99 & 2,74 \\
\hline $2005-5009$ & 2005 & 3,14 & 3,22 & 2,89 & 3,22 & 3,15 & 3,13 & 2,99 \\
& 2009 & 3,17 & 3,23 & 3,09 & 2,97 & 3,15 & 3,07 & 2,97 \\
\hline \multirow{2}{2}{$009-2013$} & 2009 & 3,24 & 3,31 & 3,16 & 3,00 & 3,21 & 3,09 & 2,86 \\
& 2013 & 3,32 & 3,33 & 3,29 & 3,26 & 3,29 & 3,29 & 3,06 \\
\hline
\end{tabular}


A8. Explaining satisfaction with democracy (1-5), Ordinal logistic latent growth models

\begin{tabular}{|c|c|c|c|c|c|}
\hline & & $\begin{array}{l}\text { Model } 1 \\
\text { Unconditional } \\
\text { growth }\end{array}$ & $\begin{array}{l}\text { Model } 2 \\
\text { Dynamic } \\
\text { party } \\
\text { preference }\end{array}$ & $\begin{array}{c}\text { Model } 3 \\
\text { Dynamic party } \\
\text { preference with } \\
\text { controls }\end{array}$ & $\begin{array}{c}\text { Model } 4 \\
\text { Fixed party } \\
\text { preference }\left(\mathrm{t}_{1}\right) \\
\text { with controls }\end{array}$ \\
\hline \multicolumn{6}{|l|}{ Fixed effects } \\
\hline \multirow[t]{30}{*}{ Initial status } & \multicolumn{5}{|l|}{ Party preference (ref: AP) } \\
\hline & \multirow[t]{2}{*}{ Rødt } & & $-1.092^{*}$ & $-1.211^{*}$ & $-1.621^{* *}$ \\
\hline & & & $(0.472)$ & $(0.500)$ & $(0.607)$ \\
\hline & \multirow[t]{2}{*}{ SV } & & -0.184 & -0.147 & 0.156 \\
\hline & & & $(0.340)$ & $(0.369)$ & $(0.433)$ \\
\hline & \multirow[t]{2}{*}{ SP } & & -0.436 & -0.520 & $-1.395^{* *}$ \\
\hline & & & $(0.365)$ & $(0.357)$ & $(0.388)$ \\
\hline & \multirow[t]{2}{*}{ Krf } & & -0.154 & $-0.549^{*}$ & $-1.422^{* *}$ \\
\hline & & & $(0.226)$ & $(0.247)$ & $(0.508)$ \\
\hline & \multirow[t]{2}{*}{$\mathrm{V}$} & & -0.448 & $-0.938^{* * *}$ & $-1.390^{* * *}$ \\
\hline & & & $(0.304)$ & $(0.325)$ & $(0.385)$ \\
\hline & \multirow[t]{2}{*}{$\mathrm{H}$} & & $-0.888^{* *}$ & $-2.133^{* *}$ & $-1.898^{* *}$ \\
\hline & & & $(0.190)$ & $(0.218)$ & $(0.225)$ \\
\hline & \multirow[t]{2}{*}{ FrP } & & $-1.069^{* *}$ & $-2.268^{* * *}$ & $-3.791^{* *}$ \\
\hline & & & $(0.209)$ & $(0.234)$ & $(0.276)$ \\
\hline & \multirow[t]{2}{*}{ MDG } & & $-1.261^{* *}$ & $-1.608^{* * *}$ & $-2.383^{* * *}$ \\
\hline & & & $(0.391)$ & $(0.428)$ & $(0.559)$ \\
\hline & \multirow[t]{2}{*}{ No party preference } & & $-2.324^{* *}$ & $-2.836^{* *}$ & $-4.486^{* *}$ \\
\hline & & & $(0.463)$ & $(0.484)$ & $(0.792)$ \\
\hline & Lower educated (ref: middle) & & & -0.194 & $-0.325^{+}$ \\
\hline & & & & $(0.131)$ & $(0.170)$ \\
\hline & Higher educated (ref: middle) & & & $0.646^{* *}$ & $0.544^{* *}$ \\
\hline & & & & $(0.092)$ & $(0.130)$ \\
\hline & Age (categorical, 7 categories) & & & $0.050^{+}$ & $0.096^{* *}$ \\
\hline & & & & $(0.026)$ & $(0.037)$ \\
\hline & Female (ref: male) & & & $0.407^{* *}$ & 0.103 \\
\hline & & & & $(0.081)$ & $(0.113)$ \\
\hline & Satisfaction with government & & & $1.027^{* *}$ & $0.797^{* *}$ \\
\hline & (categorical, 5 categories) & & & & \\
\hline & & & & $(0.053)$ & $(0.069)$ \\
\hline Change rates & Intercept & $-0.267^{* *}$ & $-0.334^{* *}$ & $-0.419^{* * *}$ & $-0.426^{* *}$ \\
\hline & & $(0.015)$ & $(0.029)$ & $(0.031)$ & $(0.033)$ \\
\hline & Party preference (ref: AP) & & & & \\
\hline & $\mathrm{R} \varnothing \mathrm{dt}$ & & -0.134 & -0.062 & -0.039 \\
\hline & & & $(0.101)$ & $(0.105)$ & $(0.126)$ \\
\hline & SV & & -0.013 & 0.036 & -0.047 \\
\hline & & & $(0.075)$ & $(0.079)$ & $(0.090)$ \\
\hline & SP & & -0.112 & -0.106 & 0.064 \\
\hline & & & $(0.073)$ & $(0.074)$ & $(0.082)$ \\
\hline & Krf & & 0.023 & -0.009 & $0.245^{*}$ \\
\hline & & & $(0.069)$ & $(0.070)$ & $(0.108)$ \\
\hline & $\mathrm{V}$ & & $0.190^{*}$ & $0.195^{*}$ & $0.300^{* * *}$ \\
\hline & & & $(0.081)$ & $(0.081)$ & $(0.078)$ \\
\hline & $\mathrm{H}$ & & $0.154^{* *}$ & $0.189^{* *}$ & $0.176^{* *}$ \\
\hline & & & $(0.041)$ & $(0.044)$ & $(0.046)$ \\
\hline & FrP & & $0.119^{* *}$ & $0.150^{* *}$ & $0.173^{* *}$ \\
\hline & & & $(0.046)$ & $(0.048)$ & $(0.053)$ \\
\hline & MDG & & 0.086 & $0.180^{+}$ & $0.289^{*}$ \\
\hline & & & $(0.087)$ & $(0.093)$ & $(0.118)$ \\
\hline & No party preference & & 0.164 & $0.224^{*}$ & $0.247^{+}$ \\
\hline & & & $(0.106)$ & $(0.113)$ & $(0.146)$ \\
\hline Cut off points & Cut off 1 & $-9.097^{* *}$ & $-9.840^{* * *}$ & $-6.855^{* * *}$ & $-7.768^{* * *}$ \\
\hline & & $(0.184)$ & $(0.235)$ & $(0.294)$ & $(0.389)$ \\
\hline & Cut off 2 & $-5.938^{* *}$ & $-6.659^{* *}$ & $-3.551^{* *}$ & $-4.441^{* * *}$ \\
\hline & & $(0.120)$ & $(0.175)$ & $(0.258)$ & $(0.337)$ \\
\hline & Cut off 3 & $-2.615^{* *}$ & $-3.309^{* * *}$ & -0.085 & $-1.087^{* * *}$ \\
\hline & & $(0.079)$ & $(0.144)$ & $(0.248)$ & $(0.320)$ \\
\hline & Cut off 4 & $3.001^{* *}$ & $2.305^{* *}$ & $5.654^{* *}$ & $4.414^{* *}$ \\
\hline & & $(0.085)$ & $(0.141)$ & $(0.265)$ & $(0.335)$ \\
\hline Variance compo & & & & & \\
\hline Level 2 & In initial status & $12.351^{* *}$ & $11.484^{* *}$ & $12.215^{* *}$ & $7.661^{* *}$ \\
\hline & & $(0.696)$ & $(0.791)$ & $(0.854)$ & $(0.541)$ \\
\hline & In rate of change & $0.368^{* *}$ & $0.350^{* * *}$ & $0.356^{* *}$ & $0.224^{* *}$ \\
\hline & & $(0.032)$ & $(0.036)$ & $(0.038)$ & $(0.026)$ \\
\hline & Covariance & $-1.204^{* *}$ & $-1.153^{* *}$ & $-1.324^{* * *}$ & $-0.645^{* * *}$ \\
\hline & & $(0.118)$ & $(0.140)$ & $(0.151)$ & $(0.084)$ \\
\hline Goodness-of-fit & Log lik. & -24356.224 & -20009.523 & -18609.866 & -9886.690 \\
\hline
\end{tabular}




\begin{tabular}{llcccc}
\hline $\mathrm{N}$ & Observations & 22323 & 18911 & 18061 & 9581 \\
& Number of individuals & 8241 & 7567 & 7225 & 3072 \\
& Waves & 7 & 7 & 7 & 7 \\
\hline Standard errors in parentheses & & & &
\end{tabular}
${ }^{+} p<0.10,{ }^{*} p<0.05,{ }^{* *} p<0.01$ 
A9. Explaining satisfaction with democracy using multiple imputation, Latent growth models

\begin{tabular}{|c|c|c|c|c|}
\hline & & $\begin{array}{c}\text { Model } 1 \\
\text { Unconditional } \\
\text { growth }\end{array}$ & $\begin{array}{c}\text { Model } 2 \\
\text { Dynamic party } \\
\text { preference }\end{array}$ & $\begin{array}{c}\text { Model } 3 \\
\text { Dynamic party } \\
\text { preference } \\
\text { with controls }\end{array}$ \\
\hline \multicolumn{5}{|l|}{ Fixed effects } \\
\hline \multirow[t]{29}{*}{ Initial status } & Intercept & $\begin{array}{l}3.970^{* *} \\
(0.008)\end{array}$ & $\begin{array}{l}4.079^{* *} \\
(0.014)\end{array}$ & $\begin{array}{l}3.336^{* *} \\
(0.033)\end{array}$ \\
\hline & Party preference (ref: AP) & & & \\
\hline & $\mathrm{R} ø \mathrm{dt}$ & & $\begin{array}{c}-0.225^{* *} \\
(0.049)\end{array}$ & $\begin{array}{c}-0.227^{* *} \\
(0.048)\end{array}$ \\
\hline & SV & & $-0.076^{*}$ & $\begin{array}{l}(0.040) \\
-0.062^{+}\end{array}$ \\
\hline & & & $(0.033)$ & $(0.033)$ \\
\hline & SP & & $-0.102^{* *}$ & $-0.143^{* *}$ \\
\hline & & & $(0.036)$ & $(0.036)$ \\
\hline & Krf & & -0.031 & $-0.115^{* *}$ \\
\hline & & & $(0.026)$ & $(0.004)$ \\
\hline & $\mathrm{V}$ & & $-0.118^{* *}$ & $-0.207^{* * *}$ \\
\hline & & & $(0.029)$ & $(0.029)$ \\
\hline & $\mathrm{H}$ & & $-0.145^{* *}$ & $-0.357^{* *}$ \\
\hline & & & $(0.021)$ & $(0.022)$ \\
\hline & FrP & & $-0.217^{* *}$ & $-0.418^{* *}$ \\
\hline & & & $(0.024)$ & $(0.025)$ \\
\hline & MDG & & $-0.212^{* *}$ & $-0.264^{* * *}$ \\
\hline & & & $(0.036)$ & $(0.036)$ \\
\hline & No party preference & & $-0.562^{* *}$ & $-0.609^{* *}$ \\
\hline & & & $(0.049)$ & $(0.047)$ \\
\hline & Lower educated (ref: middle) & & & $-0.055^{*}$ \\
\hline & & & & $(0.022)$ \\
\hline & Higher educated (ref: middle) & & & $0.142^{* *}$ \\
\hline & & & & $(0.014)$ \\
\hline & Age (categorical, 7 categories) & & & $0.020^{* * *}$ \\
\hline & & & & $(0.004)$ \\
\hline & Female (ref: male) & & & $0.090^{* *}$ \\
\hline & & & & $(0.013)$ \\
\hline & Satisfaction with government & & & $0.177^{* *}$ \\
\hline & (categorıcal, 5 categories) & & & $(0.006)$ \\
\hline \multirow[t]{21}{*}{ Change rates } & Intercept & $-0.061^{* *}$ & $-0.074^{* *}$ & $-0.083^{* * *}$ \\
\hline & & $(0.002)$ & $(0.004)$ & $(0.004)$ \\
\hline & Party preference (ref: AP) & & & \\
\hline & $\mathrm{R} \varnothing \mathrm{dt}$ & & -0.017 & -0.009 \\
\hline & & & $(0.013)$ & $(0.013)$ \\
\hline & SV & & -0.010 & 0.013 \\
\hline & & & $(0.009)$ & $(0.009)$ \\
\hline & SP & & -0.013 & -0.006 \\
\hline & & & $(0.009)$ & $(0.009)$ \\
\hline & Krf & & 0.014 & $0.021^{*}$ \\
\hline & & & $(0.009)$ & $(0.009)$ \\
\hline & $\mathrm{V}$ & & $0.043^{* *}$ & $0.050^{* *}$ \\
\hline & & & $(0.009)$ & $(0.009)$ \\
\hline & $\mathrm{H}$ & & $0.027^{* * *}$ & $0.039^{* *}$ \\
\hline & & & $(0.006)$ & $(0.006)$ \\
\hline & FrP & & $0.024^{* *}$ & $0.034^{* *}$ \\
\hline & & & $(0.010)$ & $(0.006)$ \\
\hline & MDG & & 0.027 & $0.038^{* *}$ \\
\hline & & & $(0.011)^{*}$ & $(0.011)$ \\
\hline & No party preference & & $0.036^{* *}$ & $0.040^{* *}$ \\
\hline & & & $(0.013)$ & $(0.013)$ \\
\hline \multicolumn{5}{|c|}{ Variance components } \\
\hline \multirow[t]{2}{*}{ Level 1} & Within-person & $0.541^{* *}$ & $0.541^{* *}$ & $0.535^{* *}$ \\
\hline & & $(0.003)$ & $(0.003)$ & $(0.003)$ \\
\hline \multirow[t]{6}{*}{ Level 2} & In initial status & $0.574^{* *}$ & $0.551^{* *}$ & $0.536^{* *}$ \\
\hline & & $(0.008)$ & $(0.008)$ & $(0.008)$ \\
\hline & In rate of change & $0.072^{* *}$ & $0.071^{* *}$ & $0.067^{* *}$ \\
\hline & & $(0.003)$ & $(0.003)$ & $(0.003)$ \\
\hline & Covariance & $-0.139^{* *}$ & $-0.131^{* *}$ & $-0.210^{* * *}$ \\
\hline & & $(0.036)$ & $(0.038)$ & $(0.037)$ \\
\hline
\end{tabular}

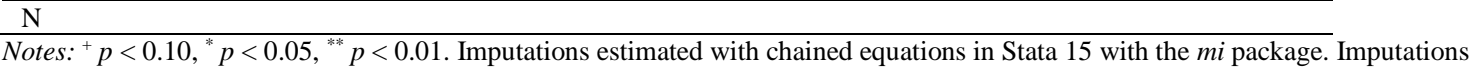
based on all independent and the dependent variables included in model 3. 
Figure A1. Mean satisfaction with democracy by country in Europe (0-10)

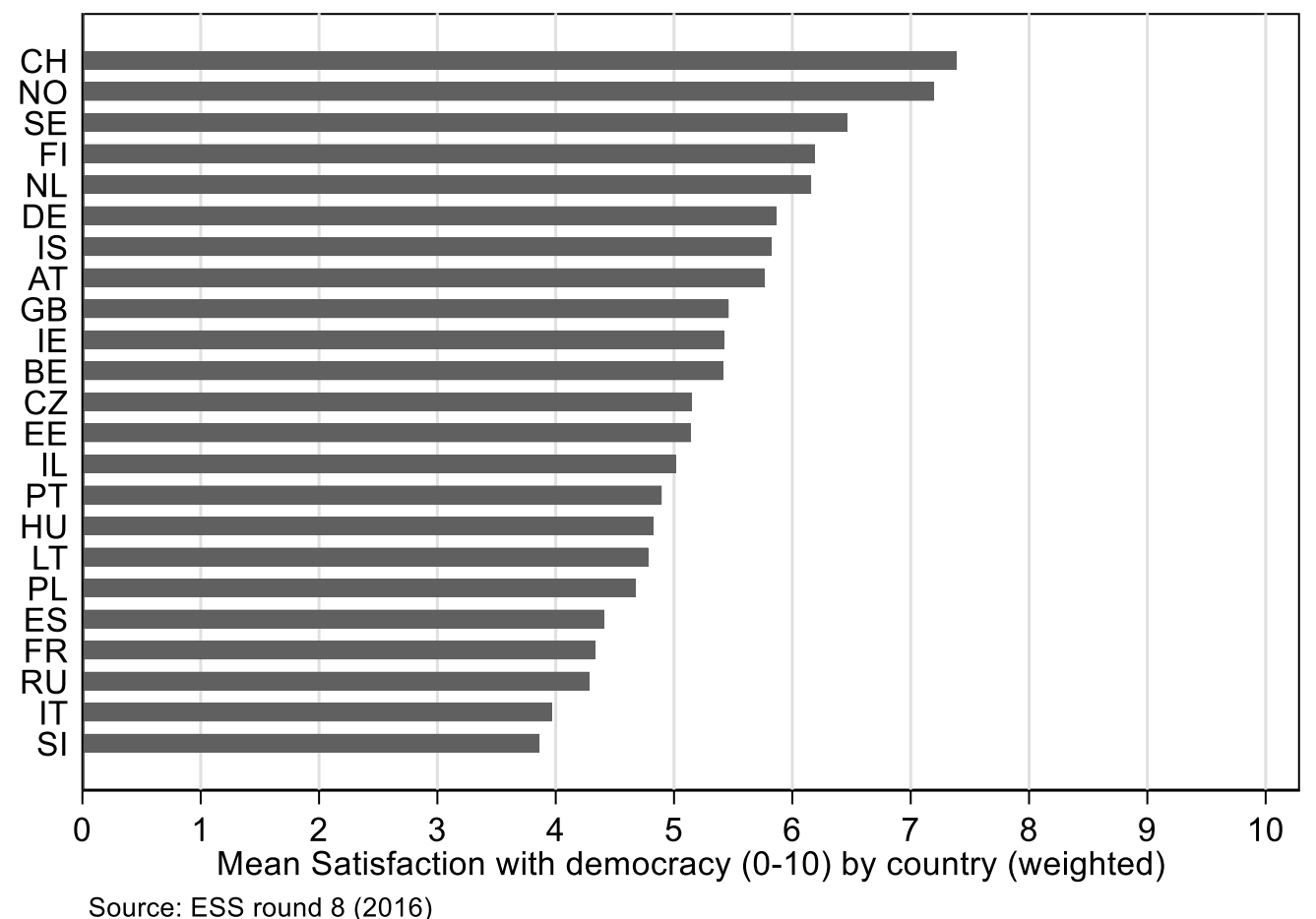

